\title{
Feckham, Peckham, Fulham, Clapham... Hammersmith: Beckett at Riverside Studios
}

Book or Report Section

Accepted Version

McFrederick, M. (2016) Feckham, Peckham, Fulham, Clapham...Hammersmith: Beckett at Riverside Studios. In:

Tucker, D. and McTighe, T. (eds.) Staging Beckett in Great Britain. Bloomsbury, Methuen Drama, London, pp. 37-55. ISBN 9781474240178 Available at http://centaur.reading.ac.uk/86787/

It is advisable to refer to the publisher's version if you intend to cite from the work. See Guidance on citing.

Publisher: Bloomsbury, Methuen Drama

All outputs in CentAUR are protected by Intellectual Property Rights law, including copyright law. Copyright and IPR is retained by the creators or other copyright holders. Terms and conditions for use of this material are defined in 
the End User Agreement.

www.reading.ac.uk/centaur

\section{CentAUR}

Central Archive at the University of Reading

Reading's research outputs online 


\title{
Feckham, Peckham, Fulham, Clapham...Hammersmith: Beckett at
}

\section{Riverside Studios}

\author{
Matthew McFrederick
}

This chapter will examine Beckett's rehearsal periods at Riverside Studios, London, where he shaped his final directorial visions of Endgame and Waiting for Godot when he worked with the San Quentin Drama Workshop in 1980 and 1984 respectively. It will reflect on how Beckett's presence at Riverside was portrayed in newspaper reports and artistic responses at the time, on the work undertaken there and innovations arising from the rehearsals, and finally it will analyse the legacies for Beckett's drama that were stimulated by his time at the Studios.

Before discussing the rehearsals of Endgame and Waiting for Godot, it is worth briefly contextualizing Beckett's career in the British theatre prior to the 1980s. Undoubtedly his closest creative partnership was with the Royal Court Theatre, where he directed or supervised many productions of his drama until 1979. This association stretched back to George Devine's artistic directorship of the then emerging English Stage Company, when he gave Beckett a platform for the world premieres of Fin de partie and Acte sans paroles and it would prove to be the UK venue where his drama was most consistently staged during his lifetime. Beckett gained further practical theatre experience by working in more of the UK and Europe's most distinguished theatres, including the National Theatre, the Royal Shakespeare Company, the Odéon Théâtre de France and the Schiller Theater in Berlin, involving actors he was eager to collaborate with such as Patrick Magee, Klaus Herm 
and Billie Whitelaw. ${ }^{1}$ Productions of his drama failed to materialize at the Royal Court during the 1980s under the artistic directorship of Max Stafford-Clark and his last collaboration at the theatre would see him direct Happy Days with Whitelaw in 1979. The 1980s proved to be the decade in which Beckett's drama began to inhabit a range of alternative London homes. ${ }^{2}$ It was also the decade in which arguably the most significant events concerning his drama in the UK were not performances, but rather two rehearsal periods Beckett surveyed at Riverside Studios. A number of initial questions about his time at Riverside arise: how did Beckett first learn about Riverside? Why, after working in theatres often considered amongst the pinnacles of the Western theatre tradition, would Beckett rehearse his final theatre productions in an arts centre in Hammersmith? And why was Beckett working with performers he had not handpicked?

Beckett first encountered Riverside in a working capacity with the rehearsals of Endgame on 7 May 1980, though he would have been familiar with the geographical area at least since his early years at the Royal Court having attended dinner parties at George Devine's house on the Lower Mall in Chiswick. ${ }^{3}$ Indeed his later knowledge of Riverside most likely came from Devine's partner, his close friend and Royal Court scenographer, Jocelyn Herbert. Herbert was friendly with the then Riverside Programme Director and Administrator and later Artistic Director David Gothard, who suggests that Herbert may have recommended Riverside as an alternative venue for Beckett to use in London and that Beckett 'would have trusted her recommendation entirely'. ${ }^{4}$ When and how much Beckett knew about Riverside in advance of his visit remains unclear, though his correspondence reveals that he was familiar with the Studios and its management structure. ${ }^{5}$ Although one of his earliest references to the venue mistakenly calls it 'Riversdale' (Harmon 1998: 370), behind this confusion was an early endorsement for Riverside, with Beckett outlining that it 
was in contention with the Royal Court to stage Happy Days with Whitelaw in $1979 .{ }^{6}$ While this production did not materialize at Riverside, just over one year later he would find himself working in west London.

At first glance, Riverside Studios may appear an unlikely place for Beckett to finish his practical work in the British theatre. However, to think this would be a disservice to the venue's history, which deserves further examination. ${ }^{7}$ A former BBC TV Studios where $\mathrm{Dr}$ Who and Hancock's Half Hour were filmed, situated on the banks of the Thames in Hammersmith, Riverside is located at the margins of London's theatrical and artistic centre. ${ }^{8}$ Following the departure of the BBC in 1975, a charitable trust formed by Hammersmith and Fulham Council converted the buildings into two large multipurpose arts spaces before making Peter Gill the venue's first Artistic Director in 1976. Gill's opening seasons staged acclaimed productions of The Cherry Orchard (in 1978) and The Changeling (in 1979) before his departure to the National Theatre Studio. The reputation of the Studios continued to grow and in the early 1980 s it became a hub of cultural activity that programmed major international artists including Tadeusz Kantor, Dario Fo, Joan Miró, David Hockney, as well as many others. It was eclectic and often visionary in terms of discovering ground-breaking artists such as Michael Clark. Furthermore, it proved to be a place of learning for many writers, actors, dancers and artists, as Hanif Kureishi, a former employee, stated: 'Riverside was what a university should be: a place to learn and talk and work and meet your contemporaries. There was no other place like it in London' (Kureishi 2000: 4). Under the artistic directorship of Gothard in the early 1980s it earned a reputation as 'the Royal Court Theatre in exile' (Wiesner 2006: 2) with Emily Green arguing that it 'made the Fringe look dowdy, the West End look taxidermied and the National Theatre a concrete maiden' (1994). 
Beckett's presence at rehearsals was a fillip for the theatre and remains a celebrated part of the Studios' history.

Beckett was in Hammersmith primarily because of his collaborations with the San Quentin Drama Workshop, which grew out of his friendship with the former San Quentin prisoner turned actor, Rick Cluchey, who first discovered Beckett's drama in the Californian penitentiary. By coincidence they would later meet in Paris, and corresponded over a number of years with Cluchey repeatedly proposing that Beckett attend a rehearsal. His persistence would lead to Beckett working with the San Quentin group on two occasions before Riverside; he directed Cluchey in Krapp's Last Tape at the Akademie der Künste in Berlin, which opened on 27 September 1977, and their friendly collaborations continued one year later when Beckett observed their rehearsals of Endgame at the Altkirche in the spare time he had from directing Spiel at the Schiller Theater Werkstatt. Beckett was unimpressed by what he saw with the Endgame production and even had the cast reaudition for their roles. Nonetheless he did see improvements, appreciated their enthusiasm and on 18 October 1978 the group travelled to London to perform Krapp's Last Tape and Endgame at the Open Space Theatre. Their Riverside rehearsals were again the fruition of Cluchey's persistence and although Beckett had attended San Quentin rehearsals in the past, his attendance in Hammersmith would prove a more remarkable and accessible event, particularly in light of the disillusionment he voiced regarding theatre work in general to friends before the rehearsals. Indeed seven months before directing Endgame in May 1980 he stressed to Cluchey, 'Never felt so far from theatre since I first looked to it for comfort 30 years ago. Perhaps haven again some day before I go down' (Beckett 1979b). ${ }^{9}$ 


\section{Documenting Beckett}

In The Cambridge Introduction to Theatre Historiography, Thomas Postlewait stresses how performance histories depend on 'the available documentation [...] to reconstruct the event' (Postlewait 2012: 230). Documentation of rehearsals is normally limited to the notes and perspectives of the practitioners involved, as they usually signify the private and mysterious phase of a production's life, where only the cast and crew experience its creative spirit, its struggles and ecstasies. Prior to Riverside, Beckett's rehearsals were only attended by the cast, creative team, close friends or the occasional theatre employee. His Riverside rehearsals in 1980 and 1984 were more open than normal, certainly very open for someone popularly depicted as an exceptionally private man. In an unprecedented step they were also observed by artists, directors, journalists, photographers and academics, whereby the friendly, creative surroundings of Riverside made the rehearsals become an unintentional performance 'laboratory' (Wheeler 1982). This openness enabled more records to be produced than most rehearsals as those observing responded to the work in their respective mediums, and these materials have since been preserved in the University of Reading's Beckett Collection and other private collections. ${ }^{10}$ Such documents, Postlewait suggests, act as 'windows through which we can observe the[se] past events' (Postlewait 2012: 239). Indeed, reading these documents today reaffirms the assertions of Beckett's assistant director for Endgame, Gregory Mosher, who surmised 'two parallel events progressed - the production of Endgame and the tracking of a reclusive maestro' (Oppenheim 2000: 132).

Through the various accounts and archival traces of these rehearsals by journalists, photographers and artists, it is clear that Beckett's presence at Riverside generated an 'extraordinary fascination' for those in attendance (Knowlson 1987: 451). The responses epitomize how, as Postlewait notes, 'certain events, at the time they occur, get 
characterized by participants and observers as significant' (2012: 248). Part of this fascination was alluded to in the newspaper reports published, which also characterized the rehearsals as a significant event. Journalists such as Maeve Binchy and Brian Appleyard recorded their surprise at Beckett's openness, which was typified in the conversations they shared with him, as he was known to rarely speak to journalists. Notably each journalist began their article by offering their own portrait of Beckett, whereby they would describe the author's appearance almost as proof that they saw him. Before her transition to popular novelist, Binchy wrote a feature on Beckett in The Irish Times, which was reported to have angered Beckett as Binchy chose to focus on his appearance and memories of Dublin while neglecting the work on stage. ${ }^{11}$ He later saw the need to mix his anger with comedy, as actors Alan Mandell and Bud Thorpe both recalled with much amusement Beckett's response to Binchy's article, referring to her as 'Bitchy Binchy'. ${ }^{12}$ Despite Beckett's annoyance with Binchy in this instance, four years later he again allowed journalists into rehearsals for Godot, with Steve Grant offering another depiction of the playwright:

A 77-year-old man sits in the foyer of Riverside Studios all but ignored in the lunchtime buzz of rattling plates and conversation. He seems tired, occasionally rubbing his eyes, sipping at the half of Guinness in front of him on the scrubbed wooden bench. He is painfully thin, the quarter miler's wiry frame having succumbed to stiffness in the last few years; the hair, neat and silvery, is stroked up from the lined forehead in a self supporting ridge. His voice is soft, almost a whisper, a Dublin voice, lilting, musical, despite the bearer's long residence in Paris. (Grant 1984: 13) 
The written accounts of Beckett at Riverside suggest he appeared more open than usual to the presence of visitors during both the sets of rehearsals. Hugh Herbert referred to the mutual understanding that appeared to function between visitors and Beckett during rehearsals by reporting: '[Beckett] had accepted we should be there, the pretence was that we were not' (Herbert 1980). Various people attended the rehearsals, each perceiving the events differently depending on their own relationship to the man, the work and their own discipline. It became a meeting space for Beckett and friends such as Whitelaw, Alan Schneider and Shivaun O'Casey, while other new faces and strangers came to the venue to catch a glimpse. ${ }^{13}$ Beckett was largely able to overlook watchful eyes in the theatre space at the time, later jokingly referring to the events as a 'jamboree' (Beckett 1984a). Mandell who played Nagg in the 1980 Endgame - noted of the visitors that 'Beckett didn't seem to mind all the drop ins'. However, Mandell 'was not used to allowing people in to observe the rehearsal period'. ${ }^{14}$ Despite Mandell's understandable reservations as an actor, many of the stories from those attending ultimately helped publicize the San Quentin tours, while marking Riverside as a venue more closely associated with Beckett's drama.

As described above, Beckett's openness was 'a great surprise' for those who witnessed the rehearsals (Shainberg 1987), including one writer, Lawrence Shainberg, who met Beckett at Riverside for the first time in 1980 and kept in contact with him over Beckett's latter years. Shainberg described the rehearsals as a 'happy time' for Beckett, where he was 'relaxed in company' (1987) because of the rehearsal environment. Such sentiments saw new portraits of Beckett come to the fore, as Shainberg articulated in The Paris Review: 'Beckett's presence destroyed the Beckett myth for me, replacing it with something at once larger and more ordinary' (1987). Shainberg's assertions were supported by the striking photographs and drawings, which materialized as a result of Beckett's time in 
rehearsals. Some of the most iconic photographs were taken by John Minihan during these rehearsals, with his two publications Samuel Beckett: Photographs (1995) and Samuel Beckett: Centenary Shadows (2006) adding to the iconographic visual portraits of Beckett. Minihan's images are closely connected with the event and have been deposited and recycled in the venue's 'repository of cultural memory' (Carlson 2006: 2) as a means of public interface through their later use in playbills, exhibitions and even at times as the Studios' Facebook profile picture. Further images of Beckett were taken in both the 1980 and 1984 rehearsals by Chris Harris and have recently come to light through the David Gothard Collection. ${ }^{15}$ Harris's portraits also offer a new lens for viewing Beckett, which is, as Gothard suggests, 'unexpected [and] not familiar' (Wiesner 2006: 15). Through Harris's images Beckett is captured unaware and displays a more liberated character in action, which suggests his directorial precision, concentration and rapport with the San Quentin cast.

As well as photographers, Beckett also became the study of two painters: Tom Phillips and John Devane. Phillips's lithograph 'Samuel Beckett' (1984) has previously been displayed in London's National Portrait Gallery and emerged as a result of his sketches from the rehearsals. Phillips discussed his own approach to drawing Beckett by stating, 'At the beginning I did not know quite how to set about drawing him [...]. I gradually realized sitting behind, trying to form a strategy, the back of his head was as eloquent as the front, and as recognizable' (Phillips 2014). Phillips's piece complements a similar photographic study of Beckett from Harris. ${ }^{16}$ Intriguingly, both artists identify and respond to Beckett's distinctive physical features from their perspective as voyeurs of these rehearsals watching both Beckett and the onstage drama that unfolded in front of him. Their portraits both construct and contribute to the aura and depictions of Beckett's presence in rehearsals, suggesting, as 
do the aforementioned reports and interviews, the number of ways in which Beckett has been or can be read or represented from his time at the Studios. Harris and Phillips visualize a recurring representation of Beckett's time at Riverside as they show (even without a trace of face) how portrayals of this rehearsal event staged Beckett in the foreground as much as the struggle of Lucky in the background. With this image of Beckett actually in the rehearsal space in mind, this chapter will now proceed to address his practical work with the San Quentin Drama Workshop in rehearsals.

\section{Rehearsing Beckett: Endgame}

Before discussing Beckett's participation at Riverside, it is important to contextualize how both rehearsal periods were assisted by rehearsals or performances prior to his involvement. San Quentin had staged Endgame before and had been briefly observed by Beckett in Berlin, while Godot was initially directed by Walter Asmus for five weeks in Chicago. Beckett's involvement at Riverside shows how he was still working creatively with these texts as he fine tuned these existing performances with revisions and cuts, while encouraging a greater emphasis on the work's shape, pace and rhythm ahead of their tours. Many of these decisions were shaped by Beckett's continuous directorial experience as he worked on his early and later plays in performance. ${ }^{17}$

The Endgame rehearsals ran from 7 May to 22 May 1980, initially in Studio 2 as The Biko Inquest featuring Albert Finney was running in the main theatre. While Beckett could draw upon past productions, his collaborations with the San Quentin group enabled him to reread the play and develop a more structured and shaped vision of it in English. This was epitomized by how he envisaged the play's structure, as he began to see it with an eight scene structure in comparison to the sixteen he outlined in his Schiller Theater production. 
Both Schiller and Riverside rehearsals employed a greater emphasis on the play's patterning in performance; for example, Clov's inspection of the opening scene in a clockwise order (Hamm, bins, sea window, earth window) was followed by an anticlockwise arrangement as he unveiled the scene (earth window, sea window, bins, Hamm). ${ }^{18}$ His direction demanded his actors intertwine these stage patterns with choreographic precision, something that was achieved by Thorpe's adherence to mathematical symmetry for Clov's movements in and out of the kitchen to his stage left. With this in mind Beckett would write in his notebook, for example, 'C's entrance identical-same number of steps to A, same half turn away' (Gontarski 1993: 50). Beckett walked Thorpe through this choreography on stage, just as he was likely to offer actors line readings when necessary, and often surprised the actors by his active participation during rehearsals. On one occasion, to the amazement of the actors, he performed the role of Nell alongside Mandell (in the absence of Teresita Garcia Suro), a character he described as 'a whisper of life' (Thorpe). In an interview with James Knowlson, Thorpe expressed his captivation with this moment, saying 'the two of them, they could have done it [...] it was frighteningly beautiful' (1993).

Rehearsals often saw Beckett critique his work, with Mandell recalling Beckett saying 'There's too much text' in relation to lines such as Hamm's 'All is...all is...all is what? (Violently) All is what?' (Gontarski 1993: 56). Cuts, revisions and alterations characterized his direction with notable textual cuts made to the song scene and all references to the song. Excisions were also made when he decided there was too much clutter on the stage, such as the picture identified in the original editions of the text or with his descriptions of the characters when he chose for them not to have red faces. As he watched the play in performance, he saw the need for simplifications to moments such as Clov's observations with the telescope and his use of the ladder. By working practically Beckett also made 
justifications in light of the text, as he wrote in his production notebook, 'Windows not high' in order to legitimate Hamm's question 'Have you shrunk?' (Gontarski 1993: 43) These practical developments, the rapport he shared with what he called the 'San Quentinites' (quoted in Harmon 1998: 372) and the ambiance of Riverside led to a largely positive rehearsal experience for Beckett, as Mandell noted:

Beckett more than enjoyed the rehearsals. He revelled in them. Well perhaps revelled is not quite the right description. At one point I was alone with him at our London digs. [...] He told me he would not be coming to Dublin for the opening. When I asked why he said 'They'd eat me up alive.' I told him what a joy the experience had been for me. He said, 'You've given me life.' He meant, I think, the whole rehearsal period and more. ${ }^{19}$

With these experiences in hand from Hammersmith, the cast and production team departed for Dublin without Beckett on the first stop of their Irish and British tour, with little idea that they would be back at Riverside to rehearse Godot with Beckett four years later.

\section{Rehearsing Beckett: Waiting for Godot}

Original plans for San Quentin's Godot rehearsals suggested that they would take place in Paris, though Beckett showed his fondness for Riverside by writing to Cluchey 'Try for Riverside again' (Beckett 1983a). Prior to the second rehearsals he had again strongly indicated that his directing days were over, though he relented and his participation in 1984 was ultimately for the Workshop's benefit, as Cluchey told him their tour to the Adelaide Festival (and subsequent Australian dates) hinged on his direct involvement. Beckett relayed 
a message to the production's director, Walter Asmus, stating that he agreed 'mostly to satisfy the Festival's insistence that I should "survey" (as Rick put it) the production' (Beckett 1983b). As further correspondence with Cluchey suggests, Beckett was keen to underline some rules and accentuate his physical condition in advance of rehearsals:

I need assurance on 2 counts:

1. That I shall not appear in any film of proceedings in London.

2. That the general title $B$. directs $B$. will be modified as requested.

Please understand the extent of my fatigue $\&$ do not ask too much of me. (Beckett 1983c)

Although the tour was branded as 'Beckett directs Beckett', Beckett showed scepticism towards this title for the San Quentin triple bill, particularly in the case of Godot, where he was reluctant to be identified as the production's director due to his respect for Asmus, who was given the official credit. ${ }^{20}$ Beckett wrote to Cluchey stating 'Your Godot should carry the mention "in consultation with the author"' (Beckett 1983a). In turn Asmus's reflections suggest his own loyalty, as he admitted upon Beckett's arrival in London, 'I didn't justify anything. [...] I just handed it over to him all together, I didn't interfere at all, I took notes'.21

Rehearsals for Godot began on 20 February 1984, in what would be the final theatre production Beckett would work on in the UK. Asmus recalled Beckett's condition when he arrived in London, he was too 'tired to do the production [and] not really in command or the shape he had been in 10 years ago' ${ }^{22}$ Even though he made notes and changes to a 1981 Faber text of Godot prior to rehearsals, both Asmus and the cast have suggested that he felt unprepared, in comparison to past rehearsals, as he could no longer memorize the text. 
Nonetheless he still demonstrated a keen eye for the play's symmetry on stage, an attentiveness that even caught out Asmus's precise direction. For example, Asmus recalls his direction of specific entrances with Pozzo and Lucky entering audience right in Act One. In Act Two Beckett has them enter audience left, though Asmus admitted, to his own embarrassment, how he had them enter audience right again with Beckett quick to assert: 'No! No, No! It's all wrong, they enter from the other side. ${ }^{23}$

The rehearsals proved to be another opportunity for Beckett to examine Waiting for Godot and make alterations to the play in performance and to the English text. Some of these changes took into consideration his work on Warten auf Godot at the Schiller Theater, alongside further discussions with Asmus in relation to his 1978 Brooklyn Academy of Music production and his own reflections on reading the play in 1984. Some of these ideas were reaffirmed in the San Quentin production, such as the swapping of Vladimir and Estragon's jackets and trousers after Act One and the tree was also modelled on Matias's pale, thin Schiller design. Furthermore the concept of twelve Wartestellen developed in Berlin was again used by Beckett and Asmus, as they saw this as a 'major motif' for the play's 'visual structure' (McMillan and Knowlson 1994: 91). The symbiotic parallels between each pairing also developed, as, for example, Dougald McMillan and Martha Fehsenfeld noted: 'Beckett concurred with J. Pat Miller's incorporation of gestures in Lucky's monologue similar to those of Pozzo in his to create a visual parallel between the two speeches' (McMillan and Fehsenfeld 1988: 75). Inevitably this production would develop its own variations and modifications, as Beckett came to the play with more experience and practical knowledge of the theatre at a different stage in his own life, with different actors, and in different circumstances. 
Each of the San Quentin actors expressed their fondness of the rehearsal experience. Lawrence Held played Estragon in this production and described how his process developed with and without Beckett:

the basic character was there and remained; but the levels on which that basic character worked were expanded considerably. There were moments that I felt very happy with, moments that were very amusing, that had been developed in Chicago, but suddenly they had the life taken right out of them. And that, initially, was a problem for me; but that is always an actor's problem - having to accommodate the director's wishes. And in this case, the director also happens to be the writer. It became very obvious to me that Beckett's work is always in a state of flux and evolution, and that this was how he felt at this particular time, hence this is how he was going to direct it. (Quoted in Duckworth 1987: 177-8)

Part of the evolutionary process saw, as Colin Duckworth highlights, a greater 'contrast between the characters of Vladimir and Estragon' (1987: 178). Further character-specific developments were made with some of the biggest changes incorporated for the role of Pozzo; substantial cuts were made to Pozzo's speeches and much of his stage business, such as the use of his pipe. Performed by Cluchey, Beckett saw Pozzo's relationship with Lucky as less violent in this production, and he cut his numerous jerks of the rope in favour of Pozzo simply 'return[ing] to the end of the rope' (McMillan and Knowlson 1994: 23) as he organizes Lucky around the stage.

Although significant cuts were made, additions were also integrated. Notably one segment of dialogue from the original French text was restored to the English text having 
been overlooked for thirty years. Beckett contemplated three different variations though it was eventually performed (and published) as follows:

ESTRAGON: Let's go!

VLADIMIR: Where? (Moves towards ESTRAGON. Seducingly) Perhaps we'll sleep tonight in his loft. All snug and dry, our bellies full, in the hay. That's worth waiting for. No?

ESTRAGON: Not all night.

VLADIMIR: It's still day.

(Silence. Both look at the sky.) (McMillan and Knowlson 1994: 19)

Although this passage represents an addition to the text, Beckett more than often simplified the text and made the staging clearer when he could.

Time limitations once again determined the working parameters of this process, though as Cluchey asserted 'if [Beckett] had had ten more days, I'm sure he would have cut, added, cut, orchestrated, rearranged, in an endless process' (Quoted in Duckworth 1987: 179). Beckett's rigour in rehearsals demonstrates how the writer would continue to shape and discover his play through performance, even in rehearsals that would prove to be his final production of Waiting for Godot; a process that challenges the idea that a performance could be definitive or complete. Beckett's tiredness after Godot surpassed his exhaustion after Endgame, though despite this it is evident he once again had a positive experience at Riverside and described the production he surveyed as 'very presentable' (Knowlson 1996: 691). One of his highlights was the performance of J. Pat Miller as Lucky. Beckett told Miller 'he was the best Lucky he had ever seen' because of the 'overwhelming' and 'searing' way 
he delivered Lucky's speech (Knowlson 1996: 691). Of one performance by Miller, Asmus recalled 'I could feel the vibrations beside me. Beckett was trembling beside me. Lucky's speech had moved him so much. I felt tears coming to my own eyes. This holy moment. ${ }^{24}$ Beckett would be glad he praised Miller, as Miller died of AIDs shortly after the conclusion of their Australian tour. The tour would prove the culmination of Beckett's two Riverside rehearsals where San Quentin would add their productions of Endgame and Krapp's Last Tape to Godot as part of their 'Beckett directs Beckett' programme. As Beckett departed Riverside, his work and indeed this production remained for a few more days, with Gothard arranging for San Quentin to perform to local school children on 1 and 2 March 1984, which allowed Beckett's drama to reach a new generation.

\section{Beckett's Riverside legacy}

Beckett's presence at Riverside proved a significant moment in the history of the west London arts centre, re-emphasizing, at a time when the venue faced uncertainty over its future funding, that it was a venue where major international artists felt comfortable working. Through the publicity and images that materialized from Beckett's visits, Riverside was known as a venue that the playwright himself endorsed and as a result became the London venue most associated with Beckett's work in the 1980s. As Marvin Carlson alludes to, these memories would be 'consciously utilized by the theatre culture' (Carlson 2006: 8), as future publicity materials and newspaper articles would feature images of Beckett at the venue. Memories of Beckett at Riverside shaped its cultural imagination and actively stimulated its future programming, creating a legacy of his work at the Studios with renowned Beckettian performers such as Joe Chaikin in Texts (1981), Billie Whitelaw in Rockaby, Enough and Footfalls (1986) and Max Wall in Krapp's Last Tape (1986). While the 
rehearsals 'achieved a definite and substantial identity', events looked upon from this perspective can often 'exclude other events from visibility and consideration' from the cultural narratives generated (Postlewait 2012: 249). This chapter will now reflect on the lesser known production histories and legacies of Beckett's drama at Riverside which were in fact initiated as a result of Beckett's presence in Hammersmith. Following San Quentin's Endgame rehearsals in 1980 the first example of their influence on Riverside came when its programming included the acclaimed American actor, director and former leader of the Open Theater, Joe Chaikin, performing Texts in 1981. Texts was an adaptation by Chaikin and director Stephen Kent which combined Beckett's prose works Texts for Nothing and extracts from How $I t \quad s .^{25}$ Both Beckett and Chaikin were on friendly terms and corresponded as Chaikin sought advice and permission prior to staging Texts. Beckett initially offered thoughts on how he saw the material working on stage through an onstage Author whose speech was intermittently broken by a recorded voice, ${ }^{26}$ though later in a note which signals how Beckett would occasionally make exceptions for his friends, he demonstrated faith in Chaikin by writing 'I give you carte blanche to use the Texts as you please + end of $\underline{\text { How it is' }}$ (Beckett 1981). Beckett maintained an active interest in the production's development, as Chaikin and other friends updated him on its progress. When Chaikin performed at Riverside it was largely acclaimed, with critics such as Sarah Powell suggesting that Texts was an example of a production which overcame traditional assumptions about Beckett's work: 'If an evening with playwright Samuel Beckett spells gloom and doom, think again [...] Texts undermines the pessimism with a clown-comic lift' (Powell 1981). Ned Chaillet added to the production's positive reception in The Times, describing Chaikin as one of theatre's 'major innovators' before stating 'It is a tribute to $\mathrm{Mr}$ Chaikin and $\mathrm{Mr}$ Kent that [Texts] becomes mesmerising drama [...]. Mr Chaikin's 
performance [...] demonstrates that superb acting can exist well outside the English tradition' (Chaillet 1981). Through performances such as Texts Riverside demonstrated how even though Beckett was not present, they could attract acclaimed performers of Beckett's work capable of redefining assumptions attached to his oeuvre.

In the years that followed the 1984 rehearsals, Riverside's artistic directorship and management structures changed, though their commitment to Beckett's work continued as they honoured his eightieth birthday in 1986 with a number of events across the year. This season began with Whitelaw performing Rockaby, Footfalls and Enough; performances previously staged individually at the Royal Court and National where she had originally been directed by Beckett and Schneider, though restaged with the help of Robert Hendry and Rocky Greenberg. This triple bill was the first time Whitelaw had worked on Beckett's plays without his direction or supervision since she first performed in Play at the Old Vic in 1964. As well as the foremost actress Beckett collaborated with, their programming would go on to showcase the next generation of Beckettian performers including Barry McGovern in his touring production of $I^{\prime} l l$ Go On from the Gate Theatre in Dublin in July $1986 .{ }^{27}$ McGovern was already an accomplished performer of Beckett's drama in Ireland, though he would later symbolize the Gate's developed interest in Beckett's drama through his multiple performances in their Beckett productions. After what was the Gate Theatre's first visit to London with a production of Beckett's work, the Irish theatre would go on to contribute numerous productions of Beckett's drama to the London theatre landscape over a 25-year period, with performances in the West End as well as their two Beckett festivals in 1999 and 2006 at the Barbican Centre, which both staged Beckett's nineteen plays for the theatre.

Further Beckett performances and events at Riverside happened during the 1980s including Max Wall's in Krapp's Last Tape, as the venue continued to promote Beckett's 
work. As the decade drew to a close and Beckett's health deteriorated, several of his friends involved in his Hammersmith rehearsals planned a production to lift his spirits. This production of Krapp's Last Tape and Catastrophe first staged at the Leicester Haymarket would bring together a number of his close friends and collaborators within the theatre. David Warrilow played Krapp in a production directed by Beckett's Polish translator Antoni Libera, designed by Herbert with Gothard then an Artistic Associate of the Haymarket. The production also toured to Riverside and the timing of Beckett's death saw the first UK performances of Beckett's drama after his death take place in the Hammersmith arts centre. It was here in his alternative London theatrical home that the UK productions of Beckett's drama post-Beckett would start.

As stated, Beckett's participation in rehearsals at Riverside initiated a legacy of further Beckett productions at the Hammersmith venue. However, the broader impact of these rehearsals on individuals working at Riverside or directly involved in these rehearsals remains lesser known. Of the numerous people engaged in the theatre, Beckett's impact is perhaps best encapsulated by the career of the then Riverside Associate Director David Leveaux. Leveaux would go on to be a renowned Broadway director for his work on Eugene O'Neill and Pinter's plays and following his work at Riverside he would direct the first East German Beckett production with Das letzte Band at the Theater im Palast, East Berlin in 1986, featuring Ekkehard Schall. Through distanced reflection it is possible to see the impact observing Beckett in rehearsals had on individuals who were present:

I had the great fortune to sit around and watch him direct in that distinctive and discreetly influential style that depended less on him saying anything than it did on the actors being aware to their nerve endings that he didn't miss a thing. Moreover, 
and here was the clue, there was nothing abstract about his advice to the actor. Not a word about metaphors or meanings or themes, only the gently firm injunction to 'look up there' or to be clear on a word or a phrase. (Leveaux 2014)

Leveaux's comments offer a fitting reflection on Beckett's time in rehearsals at Riverside. He suggests the distinct impression Beckett's physical presence stimulated from those observing and the subtlety and conviction with which he envisaged his plays, though unmistakably he also highlights the education these rehearsals gave those in attendance.

To conclude, it is worth recalling Beckett's disillusionment with the theatre in 1979 and his hopes for a theatre 'haven' before his death. By 1984, he was 77 and inevitably left Riverside tired from his exertions over rehearsals, though he enjoyed the work, the friendly atmosphere and the venue. As the theatre encountered funding difficulties with the Greater London Council (GLC), he signed a letter alongside several prominent artists to the editor of The Times describing Riverside as 'a joyful building' (Matta et al. 1982). In later years when funding difficulties meant Riverside closed for several months Beckett wittily referred to the GLC as the 'G.L. Curmudgeons' (Beckett 1985) in a letter to Gothard, who had subsequently left Riverside. Though perhaps more significantly Beckett stated succinctly, 'Another haven closed' (ibid.). Although he was only present in Hammersmith for a number of weeks, he developed an affection for the venue and the people who helped him. His drama would continue to be staged even when he was not directly involved, underlining his position in Riverside's eclectic international programming during in the 1980s. Over these years Riverside established itself as the alternative home for Beckett's drama in London, stimulated by rehearsals which proved a significant pedagogical and public moment; where 
well-worn portraits of Beckett were redefined and a new generation of practitioners, producers and devotees were educated and inspired.

${ }^{1}$ Beckett's Schiller Theater productions of Endspiel and Das Letzte Band played in Peter Daubeny's World Theatre Seasons at the Aldwych Theatre in 1970 and 1971 and his production of Warten auf Godot was also staged at the Royal Court in 1976.

${ }^{2}$ This precedent would continue in the 1990s after his death with a notable upsurge in the West Endification and Festivalization of his work in London. During the 1980s productions of his drama returned to the National, the Young Vic and the Old Vic and even spread to alternative London locations with the Manchester Royal Exchange's tour of Waiting for Godot, featuring Max Wall at the Roundhouse.

${ }^{3}$ Riverside Studios is approximately 300 metres from Lower Mall, with Lower Mall on the west side of Hammersmith Bridge.

${ }^{4}$ Email to Matthew McFrederick, 24 April 2015.

${ }^{5}$ It is clear from a letter to Rick Cluchey of 30 July 1979 that Beckett knew Peter Gill was Artistic Director of Riverside Studios and David Gothard was its Programme Director and Administrator.

${ }^{6}$ Beckett wrote to Alan Schneider early to mid-May 1978: 'Still hopes of Happy Days with Billie next summer, at Court or perhaps Riversdale Studios, but nothing firm so far' (Harmon 1998: 370). Beckett was obviously thinking of Riverside yet his mistake may be connected to the last home of W. B. Yeats. Indeed this production of Happy Days was directed by Beckett 
at the Royal Court, in what would be the last time his drama would return to Sloane Square until 2006 with Harold Pinter's performance in Krapp's Last Tape.

${ }^{7}$ To date Riverside Studios has not been the subject of a published history, although the work of Dario Fo and Tadeusz Kantor at the Studios has been discussed in Kantor Was Here: Tadeusz Kantor in Great Britain and Dario Fo and Franca Rame's Theatre Workshops at Riverside Studios, London.

${ }^{8}$ Riverside Studios is located five miles from where Waiting for Godot was first performed at the Arts Theatre and three and a half miles from Beckett's consistent London home at the Royal Court.

${ }^{9}$ As well as Cluchey's persistence, news of the BBC's withdrawal from a proposed remake of Eh Joe, set to feature Whitelaw and Cluchey, led to Beckett offering his support to San Quentin's endeavours. Their tour was scheduled to start at the Peacock Theatre in Dublin, which would have appeared as the most practical place to rehearse, though Beckett's refusal to return to Dublin meant a viable alternative space had to be found. San Quentin also toured to the Oxford Playhouse, the Young Vic and the Arts Theatre as part of their 1980 UK and Ireland tour.

${ }^{10}$ David Gothard kindly gave me materials concerning Beckett's time at Riverside from his personal archive. These materials as well as his enthusiasm and energy have contributed to the detail of this chapter and his support is greatly appreciated.

${ }^{11}$ Binchy began her article by asserting: 'Beckett looks 54 not 74; he looks like a Frenchman, not an Irishman, and he certainly looks more like a man about to go off and do a day's hard manual work rather than direct one of his own plays for a cast which looks like him as a messiah come to rehearsal' (Binchy 1980). 
${ }^{12}$ Email to Matthew McFrederick, 9 September 2014.

${ }^{13}$ Cluchey recalled one evening after rehearsals that Beckett also met Harold Pinter at Riverside and that Pinter had arranged for them to leave for dinner in a limousine (email from Rick Cluchey to Matthew McFrederick, 24 April 2015).

${ }^{14}$ Email to Matthew McFrederick, 30 September 2014.

${ }^{15}$ These photographs were exhibited as part of '\#7 Rehearsing/Samuel Beckett', Chelsea Space, 16 John Islip Street, London, 25 March-29 April 2006.

${ }^{16}$ Harris's photograph is the cover image of the present book.

${ }^{17}$ With Endgame for instance these rehearsals could draw on the practical experience he had of observing past productions at the Royal Court (1957, 1958 and 1976), Studio des Champs-Elysées (1964), the Royal Shakespeare Company (1964) and when he directed Endspiel at the Schiller Theater Werkstatt in 1967.

${ }^{18}$ For further details see Gontarski 1993: 144.

${ }^{19}$ Email to Matthew McFrederick, 30 September 2014.

${ }^{20}$ Beckett outlined his concern to Cluchey in a letter on 9 May 1984, stating: 'I regret - to put it mildly - that our understanding has not been observed. I.e. that the general description B. directs B. (as proclaimed on front of big program) should not include Godot but be modified in this case to some more accurate formula such as "Directed by W.A. in consultation with the author". Walter does not get the great credit he deserves for this production' (1984b).

${ }^{21}$ Interview with Matthew McFrederick, 4 February 2014.

22 Ibid.

${ }^{23}$ Ibid. 
${ }^{24}$ Conversation with Matthew McFrederick, February 2014.

${ }^{25}$ Chaikin went on to direct Waiting for Godot at the Taper Too Theatre, Mark Taper Forum, Los Angeles (1990) and at Atlanta Seven Stages (1992) and a new production of Texts for Nothing with Bill Irwin at the Joseph Papp Public Theater, New York (1992).

${ }^{26}$ See Beckett 1980.

${ }^{27}$ I'll Go On played at Riverside Studios from 22 July to 10 August 1986.

\section{Bibliography}

Beckett, S. (1979a), Letter to Rick Cluchey, 6 September, JEK A/2/57, Special Collections, University of Reading.

Beckett, S. (1979b), Letter to Rick Cluchey, 4 October, JEK A/2/57, Special Collections, University of Reading.

Beckett, S. (1980), Letter to Joe Chaikin, 1 August, MS 4452, Special Collections, University of Reading.

Beckett, S. (1981), Letter to Joe Chaikin, 29 January, MS 4452, Special Collections, University of Reading.

Beckett, S. (1983a), Letter to Rick Cluchey, 23 September, JEK A/2/57, Special Collections, University of Reading.

Beckett, S. (1983b), Letter to Walter Asmus, 18 October, JEK A/2/11, Special Collections, University of Reading. 
Beckett, S. (1983c), Letter to Rick Cluchey, 2 November, JEK A/2/57, Special Collections, University of Reading.

Beckett, S. (1984a), Letter to Alan Mandell, 21 March, JEK A/2/191, Special Collections, University of Reading.

Beckett, S. (1984b), Letter to Rick Cluchey, 9 May, Box 17 Folder 16-17, Carlton Lake Collection, Harry Ransom Center, University of Texas at Austin.

Beckett, S. (1985), Letter to David Gothard, 12 March, David Gothard Collection.

Binchy, M. (1980), 'Beckett finally gets down to work - as the actors take a break', The Irish Times, 14 May: 7.

Carlson, M. (2006), The Haunted Stage: The Theatre as a Memory Machine. Ann Arbor: University of Michigan Press.

Chaillet, N. (1981), 'Beckett's work explored', The Times, 18 June: page number unknown.

Duckworth, C. (1987), 'Beckett's New Godot', in Beckett's Later Fiction and Drama, edited by J. Acheson and K. Arthur, 177-8. London: MacMillan.

Fo, D. and Rame, F. (1983), Theatre Workshops at Riverside Studios, London. London: Red Notes.

Gontarski, S. E. ed. (1993), The Theatrical Notebooks of Samuel Beckett, Volume II: Endgame. London: Faber and Faber.

Grant, S. (1984), 'What makes Samuel run', Time Out, 15-21 March: 12-15.

Green, E. (1994), 'A very tough act to follow', The Independent, 22 September: page number unknown.

Harmon, M. ed. (1998), No Author Better Served: The Correspondence of Samuel Beckett and Alan Schneider. Cambridge, MA; London: Harvard University Press. 
Herbert, H. (1980), 'Brief encounter with a stage Irishman', The Guardian, 17 May: page number unknown.

Knowlson, J. (1987), 'Beckett as Director: The Manuscript Production Notebooks and Critical Interpretation', Modern Drama, Winter: 451-65.

Knowlson, J. (1996), Damned to Fame: The Life of Samuel Beckett. London: Bloomsbury.

Knowlson, J. and Knowlson, E. (2006), Beckett Remembering Remembering Beckett. New York: Arcade Publishing.

Kureishi, H. (2000), My Beautiful Laundrette. London: Faber and Faber.

Leveaux, D. (2014), “'Waiting for Godot” by Samuel Beckett', 10 November. Available online: https://www.vice.com/en_uk/read/waiting-for-godot-by-samuel-beckett-davidleveaux-107 (accessed 27 April 2015).

Matta, R., et al. (1982), 'Riverside Studios', The Times, 9 June 1982: page number unknown. McMillan, D. and Fehsenfeld, M. (1988), Beckett in the Theatre. London: John Calder. McMillan, D. and Knowlson, J. (eds) (1994), The Theatrical Notebooks of Samuel Beckett, Volume III: Waiting for Godot. London: Faber and Faber.

Minihan, J. (1995), Samuel Beckett: Photographs. London: Secker \& Warburg. Minihan, J. (2006), Samuel Beckett: Centenary Shadows. London: Robert Hale. Murawska-Muthesius, K. and Zarzecka, N. (2011), Kantor was here: Tadeusz Kantor in Great Britain. London: Black Dog Publishing.

Oppenheim, L. (2000), Directing Beckett. Ann Arbor: University of Michigan Press. 
Phillips, T. (2014), 'Samuel Beckett'. Available online:

http://www.tomphillips.co.uk/works/portraits/item/5434-samuel-beckett (accessed 9 September 2014).

Postlewait, T. (2012), The Cambridge Introduction to Theatre Historiography. Cambridge: Cambridge University Press.

Powell, S. (1981), Review of Texts, Souvenir, 24 June: page number unknown.

Shainberg, L. (1987), 'Exorcising Beckett', The Paris Review, Fall, No. 104. 'Exorcising Beckett'. Available online: http://samuel-beckett.net/ShainExor1.html (accessed 24 June 2015).

Thorpe, B. (1993), Interview with James Knowlson, JEK A/7/78, Special Collections, University of Reading.

Wheeler, J. (1982), 'Riverside Studios - London's Performance Center on the Line', Alive, November: 39.

Wiesner, J. (2006), Rehearsing/Samuel Beckett. London: Chelsea Space. 